\title{
Agroforestry for soil health
}

\author{
Jeanne Dollinger $\cdot$ Shibu Jose
}

Received: 20 March 2018/Accepted: 20 March 2018/Published online: 23 March 2018

(C) Springer Science+Business Media B.V., part of Springer Nature 2018

\begin{abstract}
Healthy soil is one of the most critical resources for the health and sustainability of ecosystems, including agroecosystems. Although the agroforestry community has long been convinced of the soil health benefits of agroforestry practices, many of such practices remain to be fully accepted by the mainstream agriculture community. Agroforestry, as a sustainable land management practice, has shown solid evidence of its role in improving soil quality and health based on at least four decades of data gathered from the world over. This thematic issue presents 28 papers that add further to the body of knowledge to reaffirm that agroforestry can improve the major measurable soil metrics that define soil health. Collectively, these papers show that agroforestry has the ability to (1) enrich soil organic carbon better than monocropping systems, (2) improve soil nutrient availability and soil fertility due to the presence of trees in the system, and (3) enhance soil microbial dynamics, which would positively influence soil health. It is imperative that agroforestry, as part of a multifunctional land-use strategy, should receive
\end{abstract}

J. Dollinger $(\bowtie)$

UMR ECOSYS INRA-AgroParisTech, Campus de

Grignon, 78850 Thiverval-Grignon, France

e-mail: jeanne.dollinger@inra.fr

S. Jose

The School of Natural Resources, University of Missouri, 103 Anheuser Busch Natural Resources Bldg., Columbia, MO 65211, USA increased attention in our policy discussion for the future of soil and soil health.

Keywords Biodiversity $\cdot$ Climate change $\cdot$ Soil biota $\cdot$ Soil fertility $\cdot$ Soil organic carbon $\cdot$ Soil quality

\section{Introduction}

Agroforestry's potential to improve soil quality has been widely recognized as a major benefit since its inception as a scientifically recognized discipline and practice (Young 1989; Nair 2011). In recent years, there has been a renewed interest in examining soil quality and soil health as indicators of agricultural sustainability. Agroforestry practices have been promoted for decades both in the tropics and temperate regions of the world for their perceived benefits of not only improving soil quality, but also providing other ecosystem services (Jose 2009). Many of the environmental benefits and ecosystem services expected from agroforestry would not be materialized unless these practices improved the capacity of soils to be productive and healthy over the long term.

Healthy soil is arguably one of the most critical resources for the health of natural and agro ecosystems so that they can sustain food production as well as provision of ecosystem services. Although the term 'soil health' has been used synonymously with soil quality, Doran et al. (1996) defined soil health as "the 
continued capacity of soil to function as a vital living system, within ecosystem and land-use boundaries, to sustain biological productivity, maintain the quality of air and water environments, and promote plant, animal, and human health." According to the USDA, soil health is "the continued capacity of the soil to function as a vital living ecosystem that sustains plants, animals and humans" (USDA-NRCS 2018). Soil quality has been defined by the Soil Science Society of America Ad Hoc Committee on soil quality as "the capacity of a specific kind of soil to function, within natural or managed ecosystem boundaries, to sustain plant and animal productivity, maintain or enhance water and air quality, and support human health and habitation" (Karlen et al. 1997). While soil quality is used in the context of both natural and managed ecosystems, soil health is primarily used in the context of managed ecosystems, primarily agroecosystems (Lal and Stewart 2011).

The terms soil quality and soil health are used synonymously for the purpose of this thematic issue, which is a collection of papers related to some of the indicators used to assess soil health. It illustrates the role of agroforestry as a sustainable land management strategy that can improve a number of common indicators that define soil health. We have grouped the papers under three topics, the first set of papers discussing agroforestry's role in enhancing soil organic carbon (SOC), the second set dealing with soil nutrient enrichment, and the third set on soil biota.

Agroforestry enhances soil organic carbon

The SOC is a function of the rate of decomposition and replacement of the organic matter (OM) in the soil. Incorporation of trees in agroforestry enhances the soil OM by adding litter both above and belowground. Soil $\mathrm{OM}$ is the energy source of soil organisms and influences both soil biodiversity and associated soil biological functions. As a result, SOC is one of the important indicators used in assessing soil health. The first set of papers addresses the potential role of agroforestry in enhancing carbon storage and thereby reducing greenhouse gas emissions. In their paper, Ramos et al. (2018) quantified the above- and belowground $\mathrm{C}$ stock and their distribution at the landscape scale in two oil palm- and cacao-based agroforestry systems in Brazil. They estimated greater aboveground $\mathrm{C}$ (litter and living biomass) in an oil palm + cacao than in an oil palm + herbaceous system. The above-ground $\mathrm{C}$ pool was heterogeneously distributed in the landscape. They also observed that SOC constituted the greatest pool of C in these systems and that this $\mathrm{C}$ pool did not vary with the system's design. Noumi et al. (2018) compared the global C storage of Eucalyptus afforested plots with traditional Savannah in Cameroon. They observed that Eucalyptus stands stored more $\mathrm{C}$ than traditional Savannahs especially the oldest Eucalyptus stands. Osei et al. (2018) compared the soil C storage between woodlots, a maize-grazing rotation farmland and two traditional silvopastoral systems in Tanzania. SOC content did not differ significantly between these land uses though SOC in woodlots was composed of more recalcitrant $\mathrm{C}$. They explained the SOC content similarities by the relatively young age of the systems and the slow OM accumulation under semi-arid climate.

Hoosbeek et al. (2018) investigated how C, N and P stock as well as microbial respiration varied with distance from trees in silvopastoral systems composed of grazed open prairies with isolated trees, in Nicaragua. They measured higher $\mathrm{C}$ and $\mathrm{N}$ stocks under the canopy and area receiving litterfall than in the open prairie. However, OM was found to be more labile under the canopy, indicating that leaf litter deposition improves soil fertility, but most likely not the long-term SOC storage in those systems. Tree species' effect was also evidenced. Dhaliwal et al. (2018) investigated the role of both waterstable (WSA) and dry-stable aggregates (DSA) in SOC storage. They compared WSA and DSA distribution as well as SOC content between two agroforestry systems and a maize-wheat rotation in a semiarid area in India. They found that the SOC levels in both aggregate types were greater under the poplarbased and guava-based agroforestry systems than under the sole crop. These papers illustrate that land use type as well as agroforestry system design influence SOC storage efficiency.

With the aim of deriving general trends of SOC storage changes between agroforestry systems, agricultural systems and forests, Stefano and Jacobson (2018) performed a meta-analysis on the currently available literature. They found that, in general, shifting from systems without trees (un-cultivated, sole crop, pasture) to agroforestry systems resulted in an improved SOC storage. However, when shifting 
from forest to agroforestry systems, SOC storage decreased. The magnitude of the SOC storage difference when shifting from one system type to another differed with the soil profile depth considered. SOC storage potential in agroforestry systems is also likely to vary with maintenance practices like tillage, as evidenced by Borges et al. (2018) in chestnut orchards in Portugal. Indeed, they measured higher total OC, active, hot-water-extractable and particulate organic carbon in the surface horizon on the non-tilled orchard than that of the tilled orchard, both having equivalent design.

Carbon storage is not only an important indicator of soil health, but also a mechanism for climate change mitigation. It can, however, be counterbalanced by high emissions of $\mathrm{NO}_{2}$ or $\mathrm{CH}_{4}$ from soil under certain management practices and environmental conditions. Priano et al. (2018) compared SOC storage and $\mathrm{CH}_{4}$ fluxes among prairies, woodlots and silvopastoral systems in Argentina. They found that SOC was greater under systems containing trees than under pasture. They also observed that all of these systems could be a sink of $\mathrm{CH}_{4}$. In particular, silvopastoral systems and pine woodlots produced less $\mathrm{CH}_{4}$ than prairies and eucalyptus woodlots. When comparing $\mathrm{CO}_{2}, \mathrm{NO}_{2}$ and $\mathrm{CH}_{4}$ in irrigated versus rainfed shelterbelts in Canada, Amadi et al. (2018) showed that greenhouse gas emission was greatly influenced by the water regimes. Overall, greater emission was measured in irrigated vs. rainfed systems. Moreover, shelterbelts with Caragana tree, an $\mathrm{N}$ fixing species, released more $\mathrm{NO}_{2}$ than pine tree-based shelterbelts because of higher $\mathrm{N}$ availability in the soil. Moore et al. (2018) measured greenhouse gas emission differences according to soil water content and $\mathrm{N}$ fertilizer inputs between an agroforestry orchard, a row-crop plot and a riparian forest. They found that $\mathrm{N}$ fertilization increased $\mathrm{NO}_{2}$ emission, but reduced $\mathrm{CO}_{2}$ emissions. Soil saturation also played a role in reducing $\mathrm{CO}_{2}$ emissions, but it increased $\mathrm{CH}_{4}$ emission. Overall, the riparian forest emitted more greenhouse gases than the other land-uses (Amadi et al. 2018).

Agroforestry enhances soil nutrient availability

The occurrence of both competition and facilitation involving essential elements can be expected when different functional groups of plants are mixed in agroforestry systems (Jose et al. 2004). However, the facilitative role of trees in agroforestry systems through efficient cycling of nutrients is well understood, particularly in the tropics. Availability of these essential elements is an indication of soil health and the soil's capacity for sustaining production and services. The second set of papers describes how land use and agroforestry system design can modify availability of these essential nutrients in soil. Yengwe et al. (2018) evaluated the nutritive potential of Faidherbia albida intercropped with maize in Zambia. They estimated that litter inputs from $F$. albida could supply more than $18 \mathrm{~kg} \mathrm{~N} \mathrm{ha}^{-1}$ year $^{-1}$ and increase the microbial diversity and abundance. Pérez-Flores et al. (2018) measured the litter production and nutrient imports from litter in two shaded cacao systems in Mexico, one being 35 years old and the other one 55 years old. They concluded that the younger system produced $23 \%$ more litter, which was due to a greater contribution of litter from younger cacao. Indeed, cacao litter decreased with age of cacao trees while that of the shade trees remained constant and abundant. They did not observe any effect of cacao tree age on N, K, Zn or S supply by litter, but an effect on $\mathrm{P}, \mathrm{Ca}, \mathrm{Mg}, \mathrm{Fe}$ and $\mathrm{Cu}$. Partey et al. (2018) compared the $\mathrm{N}$-supply potential of tree leaves from Acacia auriculiformis, Baphia nitida, Albizia zygia, Azadirachta indica, Senna siamea, Senna spectabilis, Tithonia diversifolia, Gliricidia sepium and Leucaena leucocephala for maize fertilization in Ghana. They estimated that tree leaves could supply up to $93 \mathrm{mg} \mathrm{N}$ $\mathrm{kg}^{-1}$. The nutritive contents and mineralization rates of the leaves differed between the tree species, with $T$. diversifolia and G. sepium improving maize yield the best.

The process of litter decomposition and mineralization supplies abundant nutrient stock in agroforestry systems and consequently improves crop yields. Litter decomposition, although being the major nutrient supply pathway, can be complemented by nutrient leaching from leaves and nutrient-enriched rainfall. Limon et al. (2018) compared nutrient leaching from leaves between three tree species, Emblica officinalis, Sesbiana grandiflora and Moringa oleifera. They measured higher leaching of $\mathrm{NH}_{4}, \mathrm{~K}$ and $\mathrm{PO}_{4}$ from $S$. grandiflora and M. oleifera than from E. officinalis. Dawoe et al. (2018) calculated the nutrient content and annual fluxes in incident rain, throughfall and stemflow in shaded cacao systems and 
a forest. They concluded that K supply through rainfall was the main supply pathway, accounting for 50-65\% of total $\mathrm{K}$ supply. But, for $\mathrm{P}, \mathrm{Ca}, \mathrm{Mg}$ and $\mathrm{N}$, the rainfall contribution was low (5-21\%). Throughfall was highly enriched in nutrients compared to the other fluxes and contributed significantly to the nutrient inputs received via rainfall.

Not all the nutrient forms can be directly assimilated by plants. Nutrient speciation in soil is therefore a key factor of crop yield improvement. Nutrient availability in soil is directly affected by microbial activity and can vary with system design. Lana et al. (2018) compared OM accumulation and nutrient availability between two silvopastoral systems, one with Eucalyptus grandis and the other with Zeyheria tuberculosa in Brazil. They observed that the contents of essential macro- and micronutrients were greater in areas planted with Eucalyptus than in areas planted with Zeyherias. The same trend was observed for OM accumulation. They partly explained this difference by the presence of allelochemicals in Eucalyptus litter. de Souza et al. (2018) compared nutrient availability in soil solution between a preserved forest and a cacaocabruca agroforestry system. Of the nitrogen species analyzed, $\mathrm{NO}_{3}$ was the most abundant in the forest while dissolved organic nitrogen was the most abundant in the agroforestry system. The mineralization rate was found to be lower in the agroforestry system, which generated increased OM storage, but reduced nutrient availability. Prakash et al. (2018) compared P availability and speciation between a poplar-based agroforestry system and rice-wheat, maize-wheat and cotton-wheat rotation farmlands in India. They discovered contrasted $\mathrm{P}$ speciation with greater organic $\mathrm{P}$ and lower inorganic $\mathrm{P}$ as well as higher SOC content under agroforestry compared to other conventional land uses. Intercropping seemed to lower P nutrition due to lower P availability. Paul et al. (2018) compared SOC, $\mathrm{P}$ fractions and $\mathrm{P}$ cycling enzymes over 5 different land-uses including an uncultivated land, an apple orchard, an oak forest, wheat-maize rotation farmland and organic farming system in India. They showed that enzyme activities were very sensitive to land-use change. Soil under oak forest was the best in terms of enzyme activities, $\mathrm{MO}$ and $\mathrm{P}$ availability, followed by regularly manured apple orchard and organic farming. Salim et al. (2018) compared the soil fertility of homegardens and secondary forests with that of primary forest. They measured less organic carbon content in soil from homegarden compared to soil from secondary and primary forests, but greater $\mathrm{P}$, $\mathrm{Mg}$ and $\mathrm{Ca}$ as well as lower $\mathrm{pH}$. Overall, homegardens presented greater soil fertility than the forests despite the lower OM accumulation, because of greater nutrient availability.

Soil health can also be impacted by pollutants and toxic elements. Agroforestry, in certain circumstances and with certain plant species, can be used for phytoremediation of contaminated sites. Kaur et al. (2018) gives an insight into how agroforestry trees helped remediate contaminated farmlands in India. The authors measured the tolerance to cadmium (Cd) and $\mathrm{Cd}$ accumulation potential of four tree species, Eucalyptus tereticornis, L. leucocephala, Melia azedarach and Dalbergia sisso. They found that all tree species were relatively tolerant to $\mathrm{Cd}$ contamination, with the greatest tolerance shown for M. azedarach. The trees decreased Cd contamination by $41-52 \%$, with $M$. azedarach and L. leucocephala being the most efficient for phytoremediation in this context.

\section{Agroforestry improves soil biota}

The biota are considered critical to soil health and ecosystem sustainability because of their role in decomposition of soil OM, nutrient cycling, and thereby influencing soil chemical and physical properties, which will ultimately determine soil fertility and long-term sustainability. In recent years, a number of papers have examined soil biota within the context of agroforestry and the trend continues. Hailemariam et al. (2018) investigated the role of arbuscular mycorrhizal fungi (AMF) inoculation and water stress on $F$. aldiba seedling survival in Ethiopia. They found that AMF inoculation increased seedling growth regardless of inoculum origin and water status. AMF diversity can be affected by agroforestry system design, as evidenced by Shukla et al. (2018), which showed the influence of shade on the efficiency of bioinnocculants composed of rhizobacteria, phosphatesolubilizing bacteria and AMF. They found that the yields of all the studied plants were lower in the shade than in the full light, but the efficiency of the bioinnocculants was comparable in full sun and under shade for Glycine max, Phaseolus mungo, and Cicer arietinul and more beneficial for Vigna radiata and Pisum sativum. However, they observed less successful nodulation under shade than in full sun. 
In addition to the effect of land use, management practices such as pesticide application can also greatly affect microbial communities and thereby nutrient turnover and speciation in agroforestry systems as revealed by Afolabi and Muoghalu (2018). These authors measured the influence of fungicide use on litter decomposition and associated microorganisms in cacao plantations in Nigeria. Although no significant microbial diversity shift was detected, they measured an enhanced abundance of heterotrophic bacteria and fungi in the untreated litter. This resulted in lower decomposition rate in the fungicide-treated litter than in the untreated litter. Agroforestry can also sustain a rich microbial diversity that is essential to soil health and productivity. Dobo et al. (2018) compared the AMF diversity and spore density between nine agroforestry systems based on either Cordia, Millettia or Erythrina associated with coffee or Ensete. They found a slight effect of the system design on both density and diversity of AMF, with tree-Ensete having greater AMF diversity and density than tree-coffee and multiple species cropping systems. Zhang et al. (2018) investigated, by means of molecular techniques, how plant-tree associations in agroforestry systems shape the fungal community. In three systems, one with barley only and the two others with barley and Populus euramevicana or Taxodium distichum, they found greater fungal diversity in the rhizosphere compared to bulk soil, but no difference in the fungal diversity between the different systems. However, they measured a higher abundance of certain rhizospheric fungi in $P$. euramevicana-based systems than in T. distichum-based systems. Finally, Posada et al. (2018) evaluated the impact of management operations on AMF in coffee plantations of Mexico and Colombia characterized by contrasted management schemes from organic to the high use of fertilizers and pesticides. They found a great diversity of AMF in the different plantations, with limited influence of management intensity in Colombian plantations with richer soils and slightly improved diversity in Mexican plantations with poor acidic soils associated with light fertilizer usage.

Microbial community dynamics are also exploited for commercial products in certain agroforestry practices like forest farming. Edible mushroom production has become a profitable forest farming operation in many parts of the world. Torres-Gómez et al. (2018) compared the diversity and production of wild edible fungi between a native oak-pine forest and a Cupressus lusitanica (non-ectomycorrhizal species) plantation intermingled with ectomycorrhizal trees. They observed greater edible mushroom biomass in the native forest than in the plantation and the production had twice the market value. Although not as high in fungal diversity or mushroom production, the presence of ectomycorrhizal hosts in the plantation provided edible mushrooms which could be an important source of income while waiting for the timber trees to mature. They also concluded that interplanting with ectomycorrhizal trees could potentially improve ecosystem processes such as nutrient cycling, soil forming, and decomposition of litter in non-ectomycorrhizal plantations.

\section{Conclusion}

Healthy soil is arguably one of the most critical resources for healthy ecosystems, including agroecosystems, to provide goods and services. Globally, health of soil has been threatened for the past several decades and there has been a renewed interest in protecting and enhancing this most important resource for future generations. Agroforestry, as a sustainable land management practice, has shown solid evidence of its role in improving soil quality based on at least four decades of data gathered from the world over. This thematic issue adds further to the body of information to reaffirm that agroforestry can play a major role in improving many of the metrics used in measuring soil health. The 28 papers included in the thematic issue illustrate that agroforestry would enrich SOC better than monocropping systems, it could improve soil nutrient availability and soil fertility due to the presence of trees in the system and enhance soil microbial dynamics which would positively influence soil health. By gathering studies from the world over and presenting a wide diversity of systems and species combinations and quantifying their effects on specific processes, this thematic issue also provides some insights into better agroforestry design planning. Agroforestry is a practice that offers great promise to improve soil and soil health for current and future generations. It is imperative that the broader agriculture community and policymakers pay increased attention to agroforestry as a viable strategy to restore and sustain soil health. 


\section{References}

Afolabi OO, Muoghalu JI (2018) Effect of pesticides on microorganisms involved in litter decomposition in cacao plantation in Ile-Ife, Nigeria. Agrofor Syst. https://doi.org/ 10.1007/s10457-016-0032-y

Amadi CC, Farrell RE, Rees KCJV (2018) Dynamics of soilderived greenhouse gas emissions from shelterbelts under elevated soil moisture conditions in a semi-arid prairie environment. Agrofor Syst. https://doi.org/10.1007/ s10457-017-0112-7

Borges O, Raimundo F, Coutinho J, Gonçalves B, Oliveira I, Martins A, Madeira M (2018) Carbon fractions as indicators of organic matter dynamics in chestnut orchards under different soil management practices. Agrofor Syst. https:// doi.org/10.1007/s10457-017-0088-3

Dawoe EK, Barnes VR, Oppong SK (2018) Spatio-temporal dynamics of gross rainfall partitioning and nutrient fluxes in shaded-cocoa (Theobroma cocoa) systems in a tropical semi-deciduous forest. Agrofor Syst. https://doi.org/10. 1007/s 10457-017-0108-3

de Souza JC, Pereira MA, da Costa END, da Silva DML (2018) Nitrogen dynamics in soil solution under different land uses: Atlantic forest and cacao-cabruca system. Agrofor Syst. https://doi.org/10.1007/s10457-017-0077-6

Dhaliwal J, Kukal SS, Sharma S (2018) Soil organic carbon stock in relation to aggregate size and stability under treebased cropping systems in Typic Ustochrepts. Agrofor Syst. https://doi.org/10.1007/s10457-017-0103-8

Dobo B, Asefa F, Asfaw Z (2018) Effect of tree-enset-coffee based agro-forestry practices on arbuscular mycorrhizal fungi (AMF) species diversity and spore density. Agrofor Syst. https://doi.org/10.1007/s10457-016-0042-9

Doran JW, Sarrantonio M, Liebig MA (1996) Soil health and sustainability. Adv Agron 56:2-54

Hailemariam M, Birhane E, Gebresamuel G, Gebrekiros A, Desta Y, Alemayehu A, Muruts H, Araya T, Norgrove L (2018) Arbuscular mycorrhiza effects on Faidherbia albida (Del.) A. Chev. growth under varying soil water and phosphorus levels in Northern Ethiopia. Agrofor Syst. https://doi.org/10.1007/s10457-017-0146-X

Hoosbeek MR, Remme RP, Rusch GM (2018) Trees enhance soil carbon sequestration and nutrient cycling in a silvopastoral system in south-western Nicaragua. Agrofor Syst. https://doi.org/10.1007/s10457-016-0049-2

Jose S (2009) Agroforestry for ecosystem services and environmental benefits: an overview. Agrofor Syst 76:1-10. https://doi.org/10.1007/s10457-009-9229-7

Jose S, Gillespie AR, Pallardy SG (2004) Interspecific interactions in temperate agroforestry. Agrofor Syst 61-62:237255. https://doi.org/10.1023/B:AGFO.0000029002.85273. $9 \mathrm{~b}$

Karlen DL, Mausbach MJ, Doran JW, Cline RG, Harris RF, Schuman GE (1997) Soil quality: a concept, definition, and framework for evaluation. Soil Sci Soc Am J 61(1):4. https:// doi.org/10.2136/sssaj1997.03615995006100010001x

Kaur B, Singh B, Kaur N, Singh D (2018) Phytoremediation of cadmium-contaminated soil through multipurpose tree species. Agrofor Syst. https://doi.org/10.1007/s10457-0170141-2
Lal R, Stewart BA (eds) (2011) World soil resources and food security. CRC Press, Boca Raton

Lana ÂMQ, Lana RMQ, Lemes EM, Reis GL, Moreira GHFA (2018) Influence of native or exotic trees on soil fertility in decades of silvopastoral system at the Brazilian savannah biome. Agrofor Syst. https://doi.org/10.1007/s10457-0169998-8

Limon SH, Hossain M, Spiecker H (2018) Nutrients leaching from green leaves of three potential agroforestry tree species. Agrofor Syst. https://doi.org/10.1007/s10457-0169996-x

Moore BD, Kaur G, Motavalli PP, Zurweller BA, Svoma BM (2018) Soil greenhouse gas emissions from agroforestry and other land uses under different moisture regimes in lower Missouri River Floodplain soils: a laboratory approach. Agrofor Syst. https://doi.org/10.1007/s10457017-0083-8

Nair PKR (2011) Agroforestry systems and environmental quality: introduction. J Environ Qual 40:784-790. https:// doi.org/10.2134/jeq2011.0076

Noumi VN, Zapfack L, Hamadou MR, Djongmo VA, Witanou N, Nyeck B, Ngossomo JD, Mbobda RBT, Mapongmetsem PM (2018) Floristic diversity, carbon storage and ecological services of eucalyptus agrosystems in Cameroon. Agrofor Syst. https://doi.org/10.1007/s10457-017-0130-5

Osei AK, Kimaro AA, Peak D, Gillespie AW, Rees KCJV (2018) Soil carbon stocks in planted woodlots and Ngitili systems in Shinyanga, Tanzania. Agrofor Syst. https://doi. org/10.1007/s10457-016-0028-7

Partey ST, Thevathasan NV, Zougmoré RB, Preziosi RF (2018) Improving maize production through nitrogen supply from ten rarely-used organic resources in Ghana. Agrofor Syst. https://doi.org/10.1007/s10457-016-0035-8

Paul R, Singh RD, Patra AK, Biswas DR, Bhattacharyya R, Arunkumar K (2018) Phosphorus dynamics and solubilizing microorganisms in acid soils under different land uses of Lesser Himalayas of India. Agrofor Syst. https://doi.org/ 10.1007/s10457-017-0168-4

Pérez-Flores J, Pérez AA, Suárez YP, Bolaina VC, Quiroga AL (2018) Leaf litter and its nutrient contribution in the cacao agroforestry system. Agrofor Syst. https://doi.org/10.1007/ s10457-017-0096-3

Posada RH, de Prager MS, Heredia-Abarca G, Sieverding E (2018) Effects of soil physical and chemical parameters, and farm management practices on arbuscular mycorrhizal fungi communities and diversities in coffee plantations in Colombia and Mexico. Agrofor Syst. https://doi.org/10. 1007/s10457-016-0030-0

Prakash D, Benbi DK, Saroa GS (2018) Land-use effects on phosphorus fractions in Indo-Gangetic alluvial soils. Agrofor Syst. https://doi.org/10.1007/s10457-016-0061-6

Priano ME, Fusé VS, Mestelan S, Berkovic AM, Guzmán SA, Gratton R, Juliarena MP (2018) Afforested sites in a temperate grassland region: influence on soil properties and methane uptake. Agrofor Syst. https://doi.org/10.1007/ s10457-017-0104-7

Ramos HMN, Vasconcelos SS, Kato OR, Castellani DC (2018) Above- and belowground carbon stocks of two organic, agroforestry-based oil palm production systems in eastern Amazonia. Agrofor Syst. https://doi.org/10.1007/s10457017-0131-4 
Salim MVC, Miller RP, Ticona-Benavente CA, van Leeuwen J, Alfaia SS (2018) Soil fertility management in indigenous homegardens of Central Amazonia, Brazil. Agrofor Syst. https://doi.org/10.1007/s10457-017-0105-6

Shukla A, Kumar A, Chaturvedi OP, Nagori T, Kumar N, Gupta A (2018) Efficacy of rhizobial and phosphate-solubilizing bacteria and arbuscular mycorrhizal fungi to ameliorate shade response on six pulse crops. Agrofor Syst. https:// doi.org/10.1007/s10457-017-0070-0

Stefano AD, Jacobson MG (2018) Soil carbon sequestration in agroforestry systems: a meta-analysis. Agrofor Syst. https://doi.org/10.1007/s10457-017-0147-9

Torres-Gómez M, Garibay-Orijel R, Casas A, Pérez-Salicrup DR (2018) Ectomycorrhizal trees intermingled within Cupressus lusitanica plantations sustain the diversity and availability of edible mushrooms. Agrofor Syst. https://doi. org/10.1007/s10457-017-0081-x
USDA NRCS (2018) Healthy soil for life. https://www.nrcs. usda.gov/wps/portal/nrcs/main/soils/health/. Accessed 17 March 2018

Yengwe J, Gebremikael MT, Buchan D, Lungu O, Neve SD (2018) Effects of Faidherbia albida canopy and leaf litter on soil microbial communities and nitrogen mineralization in selected Zambian soils. Agrofor Syst. https://doi.org/10. 1007/s10457-016-0063-4

Young A (1989) Agroforestry for soil conservation. BPCC Wheatons Ltd, Exeter

Zhang Q, Zhang M, Zhou P, Fang Y, Ji Y (2018) Impact of tree species on barley rhizosphere-associated fungi in an agroforestry ecosystem as revealed by $18 \mathrm{~S}$ rDNA PCRDGGE. Agrofor Syst. https://doi.org/10.1007/s10457-0170086-5 